\title{
Implementasi Teknologi Fuzzy Logic Controller untuk Pengendalian Temperatur pada Proses Pengeringan Tembakau
}

\section{Implementation of Fuzzy Logic Controller Technology for Temperature Control on the Tobacco Drying Process}

\author{
Laxsmy Devy \\ Jurusan Teknik Elektro Politeknik Negeri Padang Kampus Limau Manis Padang \\ Telp. 0751-72590 Fax. 0751-72576 Email: laxsmy_d@yahoo.co.id
}

\begin{abstract}
Tobacco is one of the six most important commodities in Indonesia. This sector is the most strategic that can absorb millions of workers, ranging from tobacco farmers, laborers or workers to tobacco companies. One of the stages in tobacco processing is the drying process. Drying using sunlight is often distracted by erratic weather changes such as rain, this can cause the drying process to be slow and require very long drying time. Based on the above, a tobacco dryer was developed by implementing the fuzzy logic controller (FLC) method as the temperature controller and its moisture meter. This tool uses LM35DZ type temperature sensors and Soil Moisture YL-69 type moisture sensors. In addition, this artificial drying process also uses heating elements instead of heat from sunlight. Programming tool is made using Arduino uno microcontroller. When compared to conventional drying, the drying results using the tool will be superior in terms of time efficiency, human power and product quality.
\end{abstract}

Keywords: FLC, Temperature, Tobacco

\section{PENDAHULUAN}

Tembakau merupakan salah satu dari enam komoditas terpenting di Indonesia. Sektor ini termasuk industri paling strategis yang dapat menyerap jutaan tenaga kerja, mulai dari petani tembakau, buruh atau pekerja pada perusahaan rokok, tenaga ahli, maupun pemasaran. Tembakau merupakan salah satu komoditas ekspor Indonesia yang cukup banyak mendatangkan devisa. Pasaran tembakau cerutu Indonesia terbanyak adalah negaranegara Eropa yang dalam penjualannya melalui sistem pelelangan di Bremen, Jerman. Negara-negara pesaing utama produksi tembakau dari luar negeri hanyalah Amerika (Kuba dan Amerika Latin) dan Afrika (Kamerun).

Peranan tembakau rakyat dipandang sangat penting dalam bidang sosial, ekonomi dan perdagangan. Tembakau rakyat paling besar dibutuhkan dalam negeri terutama untuk perusahaan rokok. Prinsipnya pemerintah seharusnya tidak menghambat perkembangan pertanian dan kehidupan pertanian serta sedapat mungkin membantu mengembangkannya.

Indonesia merupakan salah satu negara yang memproduksi berbagai macam tembakau yang tersebar dari pulau Sumatera, Jawa, Bali sampai Nusa Tenggara. Lebih dari 100 jenis tembakau dihasilkan di Indonesia. Dari sekitar 200 juta kilogram tembakau yang diproduksi tiap tahunnya di Indonesia, 70\% adalah jenis Rajangan yang lazim digunakan untuk membuat rokok kretek.

Pada dasarnya, tembakau Indonesia dapat dikategorikan berdasarkan proses pengeringannya, yaitu flue cured (dikeringan dengan aliran uap panas di dalam bangunan pengering atau oven) untuk tipe Virginia, air cured (dianginanginkan) untuk tipe Burley, sun cured (dijemur dibawah sinar matahari) untuk tipe Rajangan, dark fire cured (pengasapan dengan bara api) untuk tembakau 'asapan', dan dark air cured (pengasapan dengan uap panas) untuk tembakau cerutu.

Pada umumnya tembakau Rajangan dapat ditemukan dalam bentuk rajangan 
halus (fine cut) dan rajangan kasar (broad cut). Rajangan halus biasa dikonsumsi untuk dibuat sendiri dengan cara 'dilinting' (roll-your-own). Sedangkan tembakau rajangan kasar dikonsumsi untuk kebutuhan pabrikan. Di Indonesia, sentra penghasil tembakau rajangan banyak dijumpai di Jawa yang meliputi Madura, Paiton, Jombang, Temanggung, Blitar, Rembang dan beberapa daerah lainnya. Selain di Jawa, tembakau rajangan juga bisa dijumpai di Sumatera, Bali, Nusa Tenggara Barat dan Nusa Tenggara Timur.

Selain dirajang, ada pula tembakau yang dikeringkan dalam bentuk di-krosok (daun utuh kering), seperti tembakau Virginia FC (flue cured), Burley AC (air cured), Krosok Kasturi SC (sun cured), dan Krosok Boyolali DFC (dark fire cured). Sebagai produk cita rasa, tembakau memerlukan tahapan proses 'ageing' atau penyimpanan sebelum diproses.

Proses panen harus dilakukan saat daun telah matang dan dalam kondisi prima untuk melalui tahap berikutnya, yaitu proses pengeringan.

Setelah dipanen, tembakau Rajangan dibiarkan kering lagi selama 2 hari di tempat teduh, kemudian dirajang dengan tangan menjadi irisan tembakau yang rata-rata terdiri dari 40 potongan per inci. Irisan yang disebut tembakau rajangan atau cut-rag ini kemudian dikeringkan di bawah sinar matahari selama 1 hingga 2 hari.

Pengeringan memainkan peranan penting dalam menentukan kualitas daun tembakau. Berbagai metode pengeringan digunakan untuk berbagai jenis tembakau: pengeringan dengan dianginkan untuk Burley, pengeringan dengan omprong untuk Virginia, serta pengeringan di bawah sinar matahari untuk jenis oriental.

Setelah dikeringkan, proses selanjutnya yaitu pemberian gula pada tembakau agar tembakau lebih terasa manis. Pada proses pengeringan terhadap kadar air dalam gula, tembakau dikeringkan secara konventional dengan sinar matahari. Ratarata pengeringan terhadap kadar air didalam gula hingga mencapai 10 terjadi salama 1 jam.

Menurut informasi petani tembakau lokal, saat musim penghujan produksi dari tembakau kering mulai menurun. Petani mengalami kesulitan dalam mengeringkan tembakau basah. Pada cuaca panas tembakau dapat dikeringkan dengan ratarata waktu penjemuran satu jam. Sedangkan pada musim hujan, pengeringan tidak optimal karena memerlukan waktu yang sangat lama. Bertambah lamanya pengeringan tersebut mengakibatkan menurunnya produksi baik kualitas maupun kuantitasnya. Pengeringan tembakau hanya dapat dilakukan pada siang hari saja, sedangkan pada malam hari tidak dapat dilakukan.

Untuk mengatasi masalah tersebut, diperlukan alat yang dapat melakukan pengeringan tembakau yang tidak terpengaruh oleh cuaca dan waktu pengeringan. Proses penjemuran alami yang digunakan petani dapat digantikan dengan suatu alat pengeringan secara otomatis, dimana sistem ini dilengkapi dengan pengendali temperatur.

Dalam beberapa hasil pengujian dan beberapa data dan literatur tentang pengeringan tembakau dihasilkan bahwa kondisi optimum untuk pengeringan tembakau ini adalah pada suhu $35^{\circ} \mathrm{C}$ sampai $45^{\circ} \mathrm{C}$. Pada kondisi cuaca tidak panas, pengeringan secara konvensional memberikan hasil dengan waktu yang lebih lama dan kualitas tembakau yang kurang memuaskan.

Beranjak dari permasalahan pengering tembakau tersebut, maka kita dapat memanfaatkan teknologi FLC dengan perangkat elektronika, dimana alat ini nantinya dilengkapi sensor suhu, sensor kelembaban, heater, serta sebuah motor pendingin. Prinsip kerjanya adalah apabila suhu di dalam box pengering lebih kecil dari set point maka suhu akan dinaikkan dan begitu juga sebaliknya. Sensor kelembaban digunakan untuk mengukur tingkat kadar air setiap saat serta untuk mengetahui penurunan kadar air dalam 
rentang waktu tertentu. Pada bagian heater digunakan alamunium voil yang bisa dipasangkan secara menyeluruh pada box pengering sehingga tembakau akan mendapatkan suhu yang merata.

Dengan adanya alat ini nantinya diharapkan proses pengaturan suhu dalam box pengering dan kadar air pada tembakau dapat dilakukan dengan proses automatisasi dan proses pengeringan tembakau lebih cepat sehingga dapat membantu permasalahan para petani tembakau saat musim penghujan datang.

\section{METODOLOGI}

Langkah-langkah yang dilakukan dalam proses penelitian ini adalah :

1. Mengidentifikasi dan merumuskan permasalahan .

2. Melakukan studi lapangan ke petani tembakau dan penyuluh pertanian untuk mendapatkan informasi proses pengeringan dengan kualitas terbaik

3. Merumuskan hipotesis terhadap informasi di lapangan.

4. Menentukan variabel yang akan dikendalikan dan mendefinikan proses kendali yang akan dilakukan

5. Membuat rancancangan penelitian

6. Mengembangkan instrumen penelitian

7. Menentukan subjek penelitaan

8. Melaksanakan penelitian.

9. Menganalisis Data

10.Merumuskan hasil penelitian dan pembahasan

Sistem pengeringan yang akan dibuat diutamakan untuk menggantikan sun cured (dijemur dibawah sinar matahari) untuk tipe Rajangan.

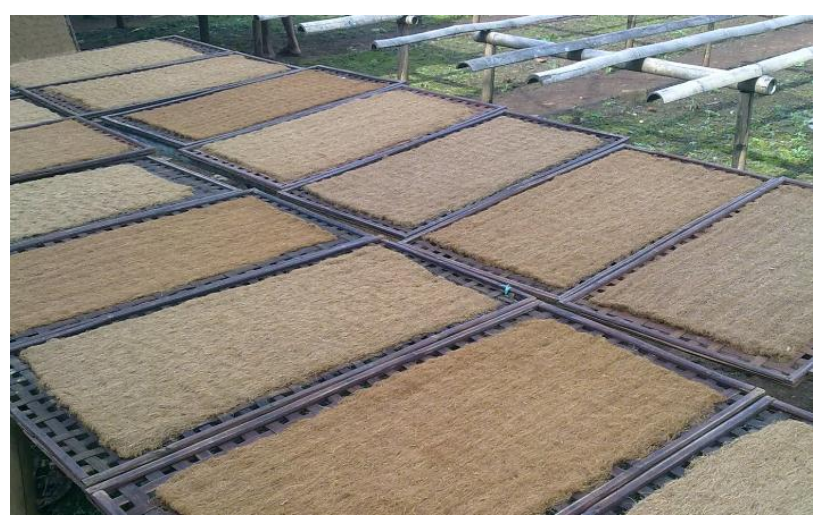

Gambar 1. Pengeringan Tembakau dengan sinar matahari

Parameter penelitian yang dilakukan adalah :

1. Sistem Minimum Mikrokontroller Arduino UnoR3 sebagai pengolah data dari input sensor dan mengendalikan temperatur menggunakan metoda $F L C$ untuk menghasil temperatur yang diiginkan

2. Temperatur yang dikendalikan berkisar $35^{\circ} \mathrm{C}$ sampai dengan $45^{\circ} \mathrm{C}$

\section{Blok Diagram Sistem}

Blok Diagram berikut merupakan gambaran sistem pengendalian temperatur untuk pengeringan tembakau :

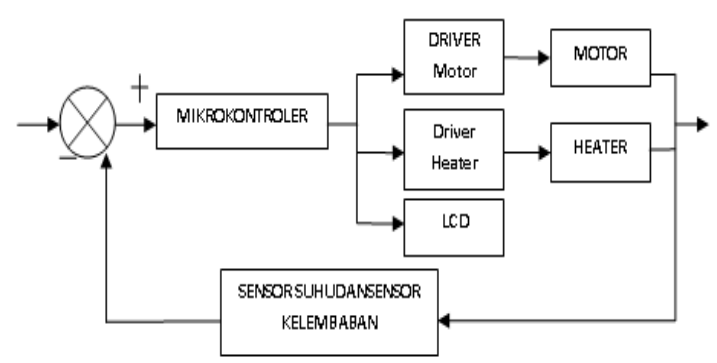

Gambar 2. Blok Diagram Sistem

Pembacaan nilai suhu dan kadar air masing-masing oleh sensor LM35 dan sensor soil moisture, nilai suhu yang dibaca merupakan nilai panas dari heater, dimana ketika alat dihidupkan heater akan langsung bekerja aktif, sedangkan untuk kadar air yang diukur dengan menggunaan sensor soil moisture yaitu nilai kadar air yang terkandung pada tembakau selama proses pengeringan berlangsung. 
Nilai dari hasil pembacaan sensor akan diproses dalam mikrokontroller, nilai ini nantinya berfungsi untuk mengatur kerja PWM motor dan relay. PWM motor fan bekerja berdasarkan metoda fuzzy dimana fan merupakan output defuzzifikasi pada fuzzy. Nilai suhu yang terbaca melebihi batas set point membuat relay akan mati dan pemanas berhenti sebaliknya ketika relay aktif pemanas akan kembali menyala. LCD pada alat merupakan media yang berfungsi untuk menampilkan nilai besaran pengukuran pada masing-masing sensor serta lamanya waktu bekerja.

Berikut ini adalah rangkaian sistem pengeringan tembakau :

\section{Rangkaian Catu Daya}

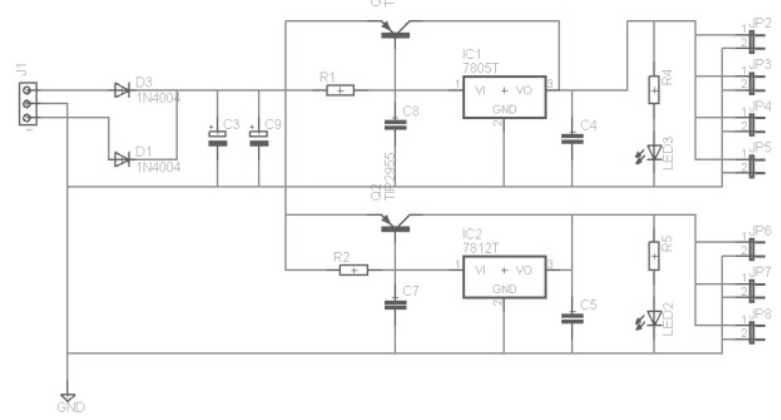

Gambar 3. Rangkaian Catu Daya

Pada rangkaian catu daya ini menggunakan rangkaian konverter yang berfungsi untuk merubah tegangan AC menjadi tegangan DC. Trafo stepdown yang digunakan adalah jenis trafo CT 2A. Gambar dibawah merupakan rangkaian konverter yang merubah tegangan AC 220 volt menjadi tegangan DC sebesar 5 volt dan 12 volt. Nilai tegangan 12 volt berfungsi untuk supply pada mikrokontroller arduino uno dan exhaust fan motor yang digunakan. Untuk tegangan 5 volt itu sendiri digunakan untuk sumber tegangan sensor yang digunakan pada alat, yaitu sensor LM35 dan sensor Soil Moisture.

\section{Rangkaian sensor LM35}

Untuk mengetahui nilai suhu yang akan diukur pada alat digunakan sensor suhu LM35DZ yang merupakan salah satu jenis dari sensor suhu. Sensor ini memiliki 1 keluaran, dimana tegangan keluaran akan berubah sesuai dengan perubahan suhu disekitar sensor berada. Sensor ini dikalibrasi langsung dalam ${ }^{\circ}$ Celcius. Sensor ini merupakan skala faktor linear $+10 \mathrm{mV} /$ ${ }^{\circ} \mathrm{C}$.

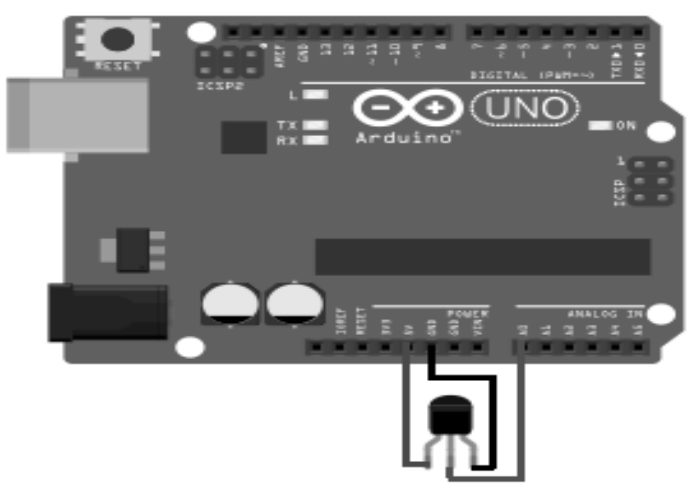

Gambar 4. Sensor Suhu LM35DZ

Output rangkaian ini akan dihubungkan ke mikrokontroller Arduino uno. Dengan demikian saat terjadi perubahan nilai tegangan pada output sensor, maka mikrokontroller Arduino uno akan mengetahui nilai perubahan tersebut, dan dapat menampilkannya pada display LCD.

\section{Rangkaian sensor Soil Moisture}

Rangkaian sensor Soil moisture terdiri dari rangkaian berupa modul IC dan 2 probes yang akan dihubungkan pada tembakau yang akan di ukur, Sensor ini yang berfungsi untuk mengukur besaran kadar air (\%) pada tembakau.

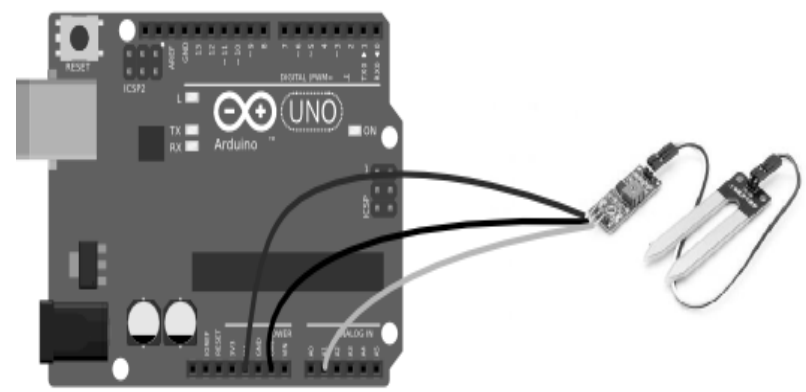

Gambar 5. Sensor Soil Moisture

\section{Rangkaian Driver Motor dc}

Rangkaian driver motor berfungsi untuk mengatur putaran kecepatan motor fan pada alat. Motor fan berfungsi untuk 
menghembuskan udara dari diluar ruang box untuk membantu proses penurunan suhu pada box. Kecepatan putaran motor fan diatur didalam proses mikrokontroler sesuai dengan Rule Base Fuzzication.Dan putaran untuk fan diberikan searah.

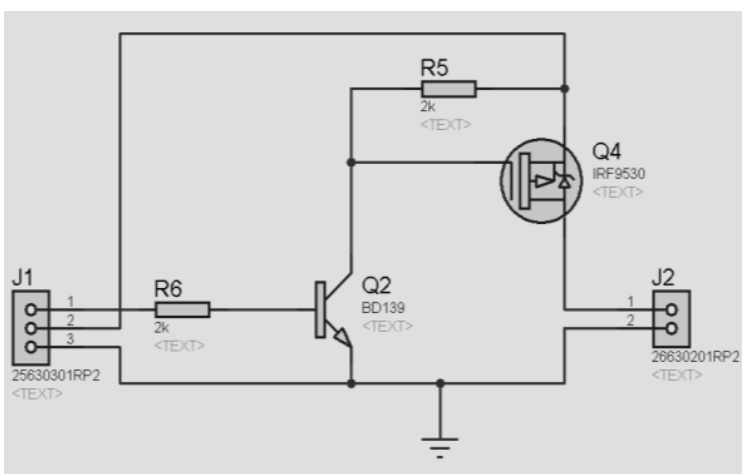

Gambar 6. Rangkaian Driver Motor

Pin konektor yang terdapat pada rangkaian pin 1 terhubung ke port 3 pada mikrokontroler sedangkan pin 2 terhubung ke ground pada mikrokontroler dan pin 3 terhubung ke supply pada power supply. MOSFET banyak digunakan pada driver karena dapat mengalirkan arus tinggi untuk menyuplai keluaran, sehingga cocok digunakan untuk driver dibanding dengan menggunakan transistor pensaklaran cepat hingga $15 \mathrm{MHz}$ dan tidak menghasilkan panas yang berlebihan saat bekerja.

\section{Rangkaian Relay}

Rangkaian Relay berfungsi sebagai saklar yang bekerja untuk menghidupkan dan mematikan heater. Kondisi ini diatur pda mikrokontrooler dimana ara kerja relay yang dapat menswitching tertutup dan terbuka ketika di beri program logika 1 dan 0 dari mikrokontrollr. Rangkaian relay terdiri dari sebuah relay, transistor, led indicator, diode dan 4 resistor.

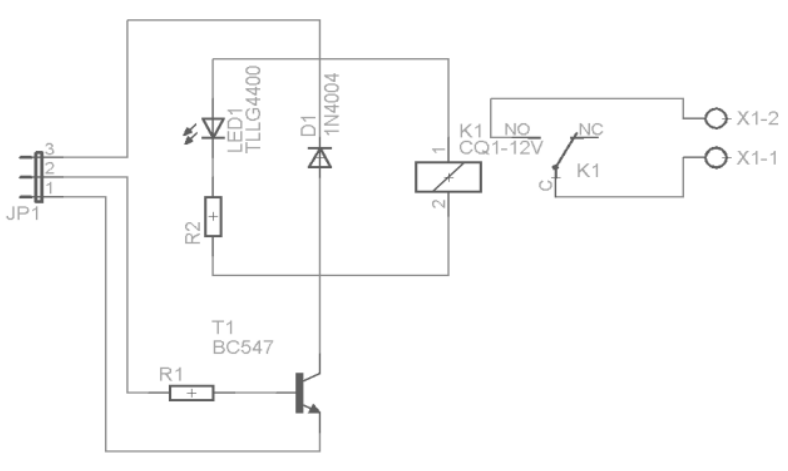

Gambar 7. Rangkaian Relay

\section{Rangkaian LCD}

Tampilan di LCD akan menunjukkan nilai pengukuran suhu di dalam alat pengering serta nilai kelembaban dai tembakau, nilai besaran suhu akan di tampilkan dengan satuan derajat celcius sedangkan nilai kelembapan dengan satuan $\%$ (persentase).

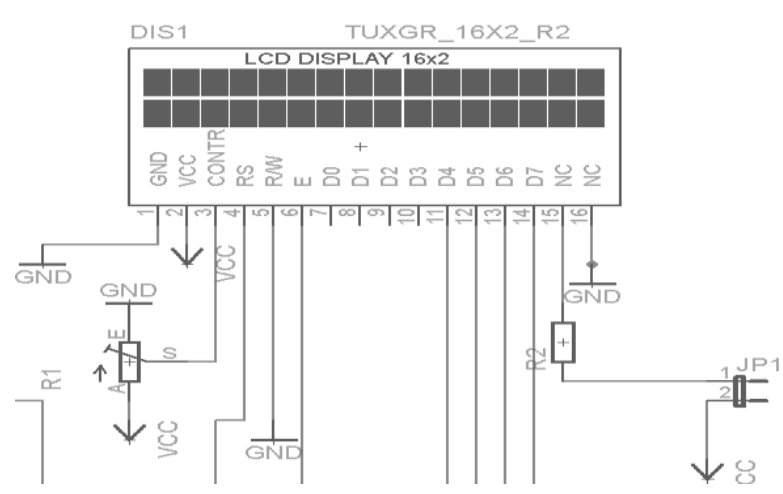

Gambar 8. Rangkaian LCD

\section{Perancangan Perangkat Lunak}

Perancangan perangkat lunak merupakan perancangan terhadap program yang digunkan pada mikrokontroller nantinya, langkah pertama membuat program adalah membuat algoritma. Algoritma merupakan garis besar jalannya suatu program. Salah satu bentuk algoritma dituangkan dalam bentuk Diagram alir (flowchart). Adapun bentuk flowchart yang dirancang dapat kita lihat pada gambar dibawah: 


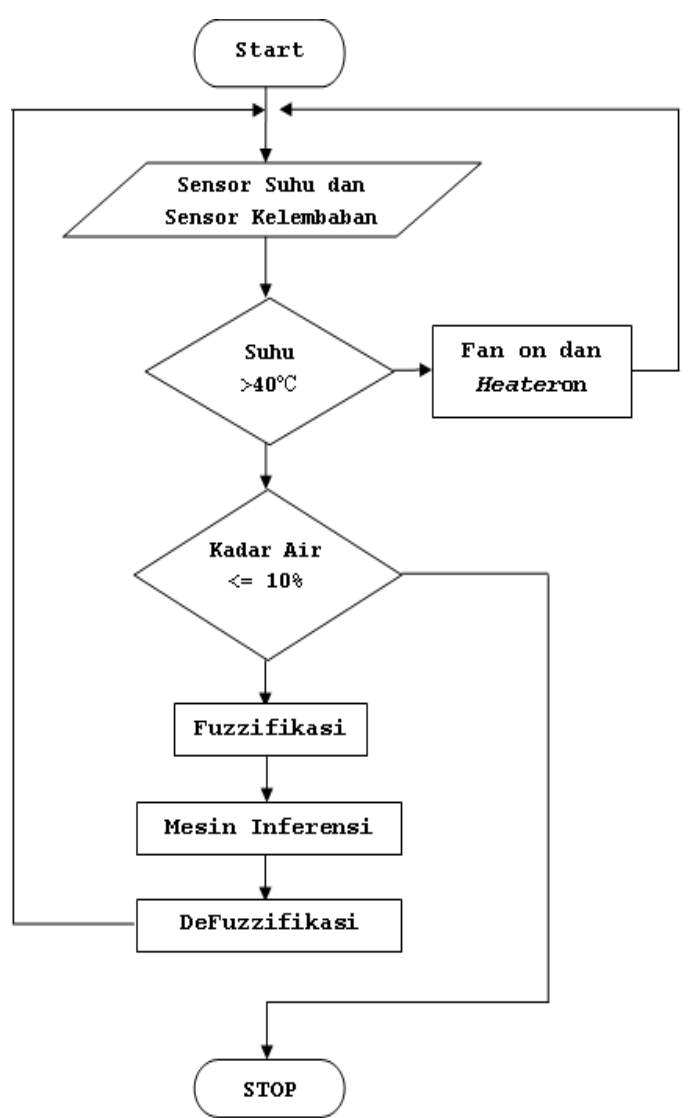

Gambar 9. Diagram alir

Flowchart di atas menggambarkan cara kerja alat secara keseluruhan, dimulai dengan start kemudian dilanjutkan dengan pembacaan suhu dan kadar air oleh kedua sensor, jika nilai kadar airnya masih bernilai diatas $10 \%$ maka alat bekerja berdasarkan Fuzzifikasi Rule yang dibuat, sehingga PWM motor akan berputar sesuai ketentuan yang dibuat dan heater akan hidup sampai batas setpoint, program akanterus berlanjut sampai kadar air yang terbaca sama dengan $10 \%$. Apabila sensor kelembaban membaca bahwa kandungan kadar air pada tembakau telah sama dengan $10 \%$ maka alat akan berhenti, artinya proses pengeringan tidak lagi dilakukan.

Perancangan untuk Fuzzy Logic Controller adalah sebagai berikut :

Sistem tahapan cara kerja fuzzy:

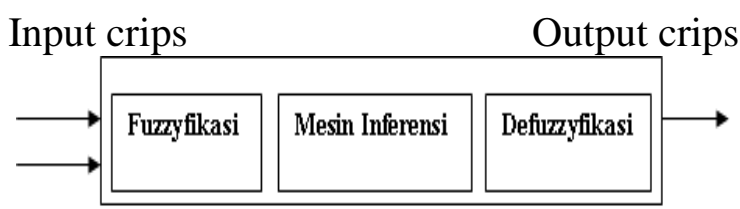

Gambar 10. Cara kerja fuzzy

\section{Fuzzifikasi :}

Fuzzifikasi adalah pembuatan Membership Function (MF) yaitu menentukan crips input dan output. Crips input yang digunakan adalah error (suhu) dan derror (kadar air) sedangkan crips output yang digunakan adalah Z (PWM motor dc).

Membership function (MF) untuk error:

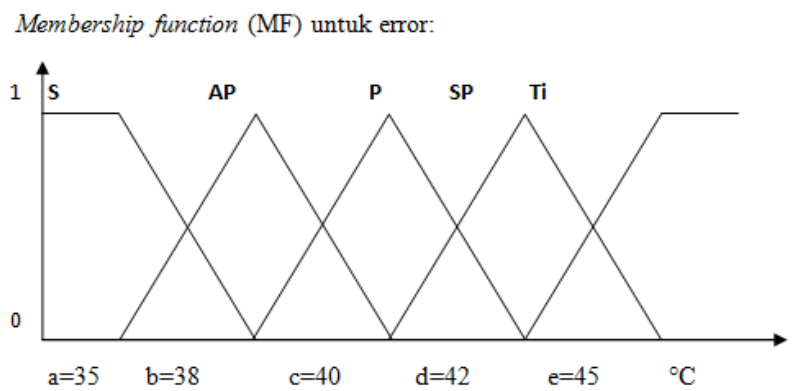

Gambar 11. Membership function (MF) untuk error

Keterangan:
a. Sedang (S)
$=$ error
b. Agak Panas (AP)
Sedang
c. Panas $(\mathrm{P})$
$=$ error Agak
Panas
d. Sangat Panas (SP)
$=$ error Panas
$=$ error
Sangat
Panas
e. Tinggi (Ti)
$=$ error Tinggi

Nilai fungsi keanggotaan pada masing-masing himpunan di buat berdasarkan range suhu yang di butuhkan di dalam pemanasan tembakau, dimana range suhu yang bagus untuk proses pemanasan tembakau yaitu antara suhu $35^{\circ} \mathrm{C}$ sampai dengan $45^{\circ} \mathrm{C}$. Berdasarkan nilai tersebutlah penulis membuatkan nilai masing-masing himpunan dari variable suhu seperti di atas sehingga nantinya suhu pemanas yang terdapat pada alat bisa sesuai dengan suhu yang diinginkan di dalam pemrosesannya.

Membership function (MF) untuk derror: 
Membership function (MF) untuk derror:

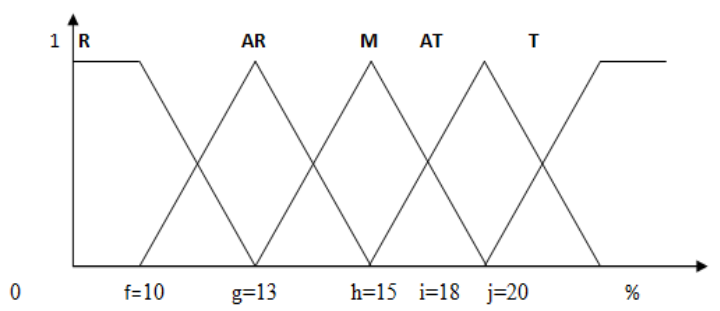

Gambar 12. Membership function (MF) untuk derror

Keterangan:
a. Rendah (R)
$=$ derror
b. Agak Rendah (AR
c. Menengah (M)
d. Agak Tinggi (AT)
e. Tinggi $(\mathrm{T})$
Rendah
$=$ derror
Agak
Rendah
$=$ derror
Menengah
$=$ derror Agak
Tinggi
$=$ derror
Tinggi

Nilai fungsi keanggotaan pada masing-masing himpunan dari variable kadar air ini berdasarkan range kadar air yang dapat dibaca oleh sensor, dimana pada sensor sendiri terdapat range nilai pembacaan berdasarkan 3 media utama, yaitu media kering, media lembab dan media air. Berdasarkan kemampuan pembacaan range dari sensor inilah maka nilai masing-masing fungsi keanggotaan tiap-tiap himpunan dibuat. Sehingga ketika nantinya kadar air tembakau yang diukur pada alat bisa langsung masuk berdasarkan kategori terhadap nilai range tersebut.
Membership function untuk output:

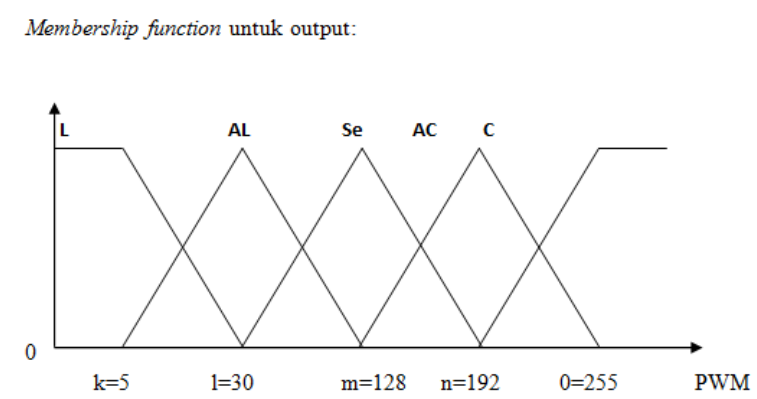

Gambar 13. Membership function (MF) untuk output

Keterangan:

a. Lambat $(\mathrm{L}) \quad=$ motor Lambat

b. Agak Lambat $(\mathrm{AL})=$ motor Agak Lambat

c. Sedang $(\mathrm{Se})=$ motor Sedang

d. Agak Cepat (AC) = motor Agak Cepat

e. Cepat $(\mathrm{C})=$ motor Cepat

\section{Mesin inferensi}

Pada Metode Tsukamoto, setiap konsekuen pada aturan yang berbentuk IFThen harus direpresentasikan dengan suatu himpunan fuzzy dengan fungsi keanggotaan yang monoton. Sebagai hasilnya, output hasil inferensi dari tiap-tiap aturan diberikan secara tegas (crips) berdasarkan $\alpha$-predikat (fire strength). Hasil akhirnya diperoleh dengan menggunakan rata-rata terbobot.

Secara umum respon fungsi step suatu system kendali memberikan output. Pada saat sistem diaktifkan, output akan bekerja dengan cepat menuju setting point (SP) yang diatur pada suhu. Output ini oleh kontroller akan diturunkan atau dinaikkan menuju SP hingga outputnya mencapai SP. Yang dilakukan oleh kontroller untuk menaikkan dan menurunkan outputharus sesuai dengan error dan derror yang terjadi. Sehinggaa kontroller dapat mengambil tindakan yang tepat untuk menyesuaikan outputnya. Dibawah ini merupakan rule dari sistem: 
Rancangan Rule Fuzzy

\begin{tabular}{|ccccc|c|} 
Error/derror & R & AR & M & AT & T \\
\hline S & L & L & L & L & L \\
AP & AL & AL & AL & AL & AL \\
P & Se & Se & Se & Se & Se \\
SP & AC & AC & AC & AC & AC \\
Ti & C & C & C & C & C \\
\hline
\end{tabular}

Gambar 14. Rule dari Sistem

Keterangan:

If error S and derror R Then PWM motor $\mathrm{L}$

If error AP and derror R Then PWM motor AL

If error $\mathrm{P}$ and derror R Then PWM motor $\mathrm{Se}$

If error SP and derror R Then PWM motor $\mathrm{AC}$

If error $\mathrm{Ti}$ and derror $\mathrm{R}$ Then $\mathrm{PWM}$ motor $\mathrm{C}$

If error $\mathrm{S}$ and derror AR Then PWM motor $\mathrm{L}$

If error $\mathrm{AP}$ and derror $\mathrm{AR}$ Then $\mathrm{PWM}$ motor AL

If error $\mathrm{P}$ and derror $\mathrm{AR}$ Then $\mathrm{PWM}$ motor $\mathrm{Se}$

If error SP and derror AR Then PWM motor AC

If error $\mathrm{Ti}$ and derror $\mathrm{AR}$ Then PWM motor $\mathrm{C}$

If error $\mathrm{S}$ and derror $\mathrm{M}$ Then PWM motor $\mathrm{L}$

If error AP and derror M Then PWM motor AL

If error $\mathrm{P}$ and derror $\mathrm{M}$ Then PWM motor $\mathrm{Se}$

If error SP and derror M Then PWM motor $\mathrm{AC}$

If error $\mathrm{Ti}$ and derror $\mathrm{M}$ Then PWM motor $\mathrm{C}$

If error $\mathrm{S}$ and derror AT Then PWM motor $\mathrm{L}$

If error AP and derror AT Then PWM motor AL

If error $\mathrm{P}$ and derror AT Then PWM motor $\mathrm{Se}$
If error SP and derror AT Then PWM motor AC

If error $\mathrm{Ti}$ and derror AT Then PWM motor $\mathrm{C}$

If error $\mathrm{S}$ and derror $\mathrm{T}$ Then PWM motor L

If error AP and derror T Then PWM motor $\mathrm{AL}$

If error $\mathrm{P}$ and derror $\mathrm{T}$ Then PWM motor $\mathrm{Se}$

If error SP and derror T Then PWM motor $\mathrm{AC}$

If error $\mathrm{Ti}$ and derror $\mathrm{T}$ Then PWM motor $\mathrm{C}$

\section{Defuzzifikasi}

Input dari proses defuzzifikasi adalah suatu himpunan fuzzy yang diperoleh dari komposisi aturan-aturan fuzzy, sedangkan output yang dihasilkan merupakan suatu bilangan pada domain himpunan fuzzy tersebut. Sehingga jika diberikan suatu himpunan fuzzy dalam range tertentu, maka harus dapat diambil suatu nilai crips tertentu sebagai output.

\section{HASIL}

\section{Pengujian Sensor Suhu}

Pengujian sensor suhu bertujuan untuk mendapatkan nilai suhu yang terukur pada pemanas (heater) sesuai dengan besaran nilai suhu yang sebenarnya. Pengujian ini dilakukan dengan menyesuaikan nilai yang terukur pada sensor suhu tipe LM35DZ dengan Thermometer sebagai tolak ukurnya.

Tabel 1. Pengujian sensor suhu

\begin{tabular}{lccc} 
No. & $\begin{array}{c}\text { Suhu Thermometer } \\
\left({ }^{\circ} \mathrm{C}\right)\end{array}$ & $\begin{array}{c}\text { Suhu terbaca LM35DZ } \\
\left({ }^{\circ} \mathrm{C}\right)\end{array}$ & $\begin{array}{c}\text { Tegangan Output Sensor } \\
\text { LN35inZ } \\
(\mathbf{m V})\end{array}$ \\
$\mathbf{1}$ & 23 & 23.05 & 230 \\
\hline $\mathbf{2}$ & 25 & 25.39 & 252 \\
\hline $\mathbf{3}$ & 28 & 28.32 & 281 \\
\hline $\mathbf{4}$ & 30 & 30.27 & 300 \\
\hline $\mathbf{5}$ & 33 & 33.20 & 331 \\
\hline $\mathbf{6}$ & 35 & 35.16 & 352 \\
\hline $\mathbf{7}$ & 38 & 38.09 & 382 \\
\hline $\mathbf{8}$ & 40 & 40.04 & 402 \\
\hline $\mathbf{9}$ & 43 & 43.46 & 432 \\
\hline $\mathbf{1 0}$ & 45 & 45.41 & 452 \\
\hline $\mathbf{1 1}$ & 48 & 48.34 & 482 \\
\hline $\mathbf{1 2}$ & 50 & 50.29 & 501 \\
\hline $\mathbf{1 3}$ & 53 & 53.22 & 532 \\
\hline $\mathbf{1 4}$ & 55 & 55.18 & 552 \\
\hline $\mathbf{1 5}$ & 58 & 58.11 & 582 \\
\hline $\mathbf{1 6}$ & 60 & 60.06 & 603 \\
\hline
\end{tabular}


Perbandingan suhu yang terbaca di Thermometer dengan sensor suhu tipe LM35D :

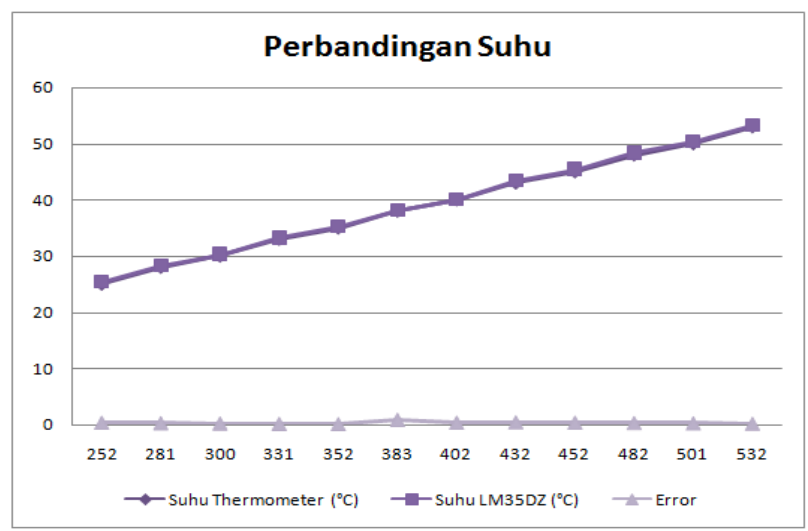

Gambar 15. Perbandingan suhu

Pengujian Sensor Kelembaban

Pada pengujian sensor kelembaban menggunakan sensor kelembaban, Arduino Uno, LCD, Moistur Meter.

Pengujian sensor kelembaban Soil Moisturetipe YL-69 bertujuan untuk mendapatkan kestabilan nilai kadar air yang diukur pada tembakau nantinya agar tidak terjadi perubahan/kesalahan yang signifikan selama proses pengeringan berlangsung. Pengujian ini dilakukan dengan membandingkan data keluaran dari sensor Soil Moisture tipe YL-69 dengan data hasil pengukuran dengan Moisture tester.

Pengujian sensor dilakukan dengan menempatkan sensor langsung pada lima kondisi media berbeda, kemudian menguji nilai besaran sensor yang terukur langsung dalam satuan persen (\%) untuk mengetahui apakah nilai yang terukur sesuai antara media yang diukur dengan rentangan batasan yang telah dimiliki oleh sensor.

Tabel 2. Pengujian sensor Kelembaban

\begin{tabular}{ccccc} 
No. & Media & $\begin{array}{c}\text { Kadar Air di Moisture } \\
\text { Meter Range 1-10 }\end{array}$ & $\begin{array}{c}\text { Data ADC Sensor Moisture } \\
\text { tipe YL-69 }\end{array}$ \\
\hline 1 & $\begin{array}{c}\text { Tanpa } \\
\text { Media }\end{array}$ & 1 & 1023 & $0 \%$ \\
\hline 2 & $\begin{array}{c}\text { Tembakau } \\
\text { Kering }\end{array}$ & 2,1 & 913 & $10 \%$ \\
\hline 3 & $\begin{array}{c}\text { Tembakau } \\
\text { Agak } \\
\text { Lembab }\end{array}$ & 2,4 & 880 & $13 \%$ \\
\hline 4 & $\begin{array}{c}\text { Tembkau } \\
\text { Lembab }\end{array}$ & 2,7 & 824 & $17 \%$ \\
\hline 5 & $\begin{array}{c}\text { Tembakau } \\
\text { Basah }\end{array}$ & 3 & 801 & $19 \%$ \\
\hline
\end{tabular}

Perbandingan tingkat kelembaban (kadar air) yang terukur di Moisture tester dengan sensor Soil Moisture tipe YL-69. :

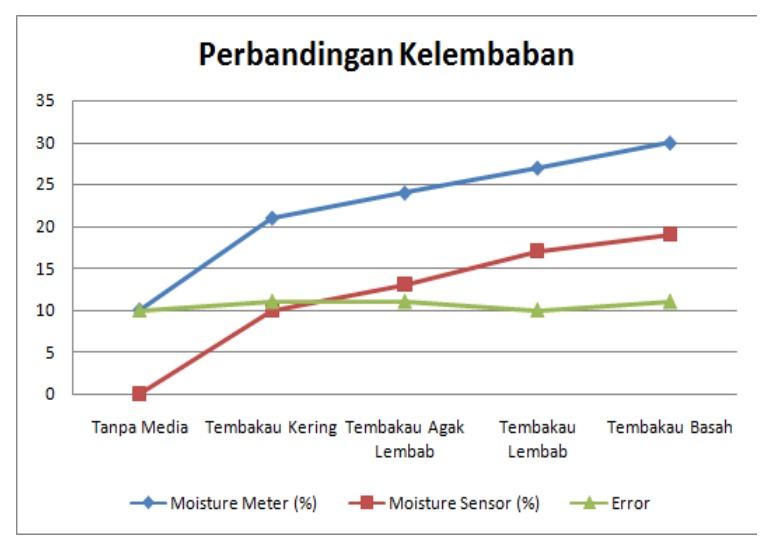

Gambar 16. Perbandingan tingkat kelembaban

\section{Pengujian Rangkaian Relay}

Pengujian rangkaian relay dilakukan dengan cara memberikan nilai masukan tegangan dari mikrokontroller Arduino Uno pada rangkaian relay dan kemudian memutuskannya. Hasil dari masukan dan keluaran relay dilihat dengan indikator LED yang terdapat pada rangkaian relay.

Tabel 3. Hasil masukan dan keluaran relay

\begin{tabular}{|cccc|}
\hline Program Mikrokontroller & Tegangan Terukur & Kondisi & Indikator \\
Arduino Uno & (Volt) & Relay & LED \\
\hline digitalWrite(relay,LOW) & 0.01 & nonAktif & Mati \\
\hline digitalWrite(relay,HIGH) & 4.25 & Aktif & Hidup \\
\hline
\end{tabular}

\section{Pengujian Driver Motor}

Pengujian driver motor DC bertujuan untuk mengetahui apakah rangkaian dapat bekerja dengan baik atau tidak. Selain itu pengujian ini bertujuan untuk mengetahui output driver motor yang dibandingkan dengan masukannya yang kemudian dapat diketahui juga hubungan keluaran Pulse Width Modulation (PWM) dengan tegangan yang dibutuhkan untuk motor DC. Rangkaian driver motor berfungsi sebagai saklar terhadap motor Exhaust fan serta untuk mengatur besaran nilai PWM pada fan.

Pada rangkaian driver motor terdapat sebuah transistor yang berfungsi 
sebagai saklar. Ketika arus mengalir menuju basis transistor atau diberi logika "1" atau dengan kata lain ada tegangan yang masuk melalui kaki basis sebesar 5 Volt maka transistor dalam kondisi saturasi, arus mengalir dari kolektor menuju ke emitor dan rangkaian driver motor akan berfungsi mengeluarkan tegangan sebesar 12 Volt DC.

Nilai logika "1" yang diberikan pada pin output driver motor berguna untuk mengatur putaran motor Exhaust fan di mana nilai PWM didasarkan dari pengolahan data fuzzifikasi pada program mikrokontroller Arduino Uno sehingga tingkat kecepatan putaran motor dapat digunakan sebagai pengontrol panas dari heater nantinya.

\section{Pengujian Sistem Keseluruhan}

Pada hasil pegujian yang telah dilakukan pada alat pengering tembakau ini didasari dengan penerapan metoda logika fuzzy sebagai pengatur suhu dan kadar air. Pengujian ini nantinya meliputi pengukuran besarnya suhu yang dihasilkan oleh alat, penurunan kadar air pada tembakau, serta lama waktu proses pengeringannya. Berikut ini adalah data hasil penelitian pengeringan tembakau:

Tabel 4. Hasil pegujian dilakukan

\begin{tabular}{|ccccc|}
\hline No. & $\begin{array}{r}\text { Walsu } \\
\text { (Menit) }\end{array}$ & $\begin{array}{c}\text { SuhuLM35 } \\
\left({ }^{\circ} \text { C) }\right.\end{array}$ & $\begin{array}{c}\text { Kadar Air Soil } \\
\text { Moisture } \\
(96)\end{array}$ & PWMMotor \\
\hline $\mathbf{1}$ & 1 & 25 & 17 & 28 \\
\hline $\mathbf{2}$ & 2 & 26 & 17 & 28 \\
\hline $\mathbf{3}$ & 3 & 27 & 17 & 28 \\
\hline $\mathbf{4}$ & 4 & 29 & 16 & 28 \\
\hline $\mathbf{5}$ & 5 & 32 & 16 & 32 \\
\hline $\mathbf{6}$ & 6 & 34 & 16 & 32 \\
\hline $\mathbf{7}$ & 7 & 35 & 15 & 32 \\
\hline $\mathbf{8}$ & $\mathbf{8}$ & 37 & 15 & 32 \\
\hline $\mathbf{9}$ & 9 & 37 & 15 & 32 \\
\hline $\mathbf{1 0}$ & 10 & 38 & 14 & 42 \\
\hline $\mathbf{1 1}$ & 11 & 38 & 14 & 42 \\
\hline $\mathbf{1 2}$ & 12 & 39 & 13 & 50 \\
\hline $\mathbf{1 3}$ & 13 & 39 & 13 & 48 \\
\hline $\mathbf{1 4}$ & 14 & 40 & 12 & 42 \\
\hline $\mathbf{1 5}$ & 15 & 41 & 12 & 42 \\
\hline $\mathbf{1 6}$ & 16 & 41 & 11 & 42 \\
\hline $\mathbf{1 7}$ & 17 & 40 & 10 & 48 \\
\hline $\mathbf{1 8}$ & 18 & 40 & 10 & 42 \\
\hline $\mathbf{1 9}$ & 19 & 39 & 9 & 0 \\
\hline & & & & \\
\hline
\end{tabular}

Pengujian dilakukan pada rangkaian keseluruhan sistem pengeringan tembakau :

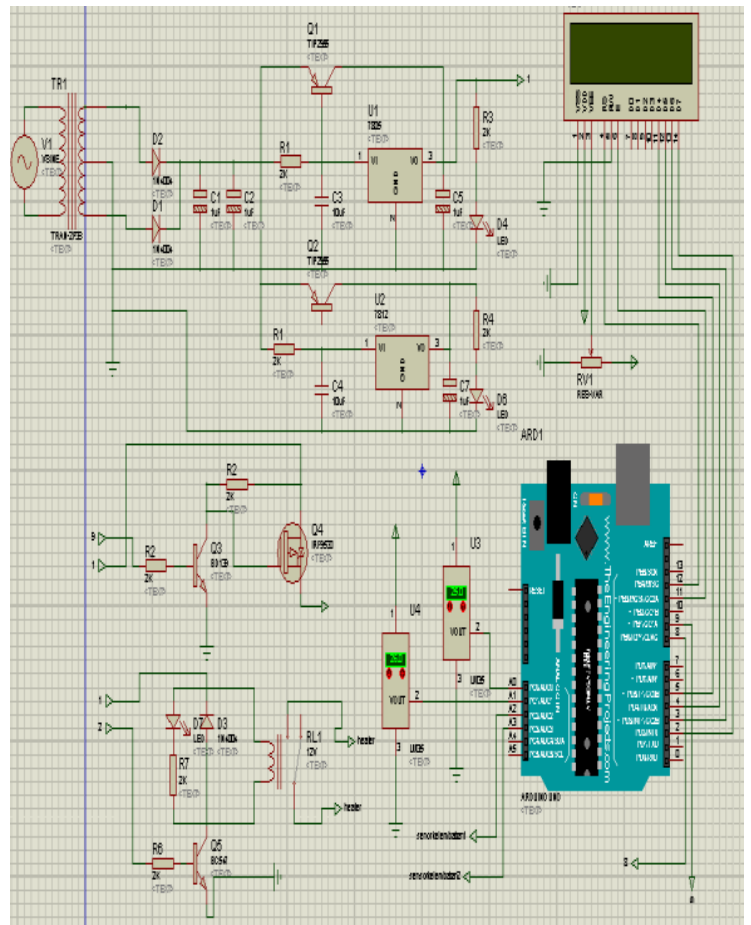

Gambar 17. Rangkaian Keseluruhan Sistem

Perbandingan suhu dan kadar air terhadap waktu pengeringan

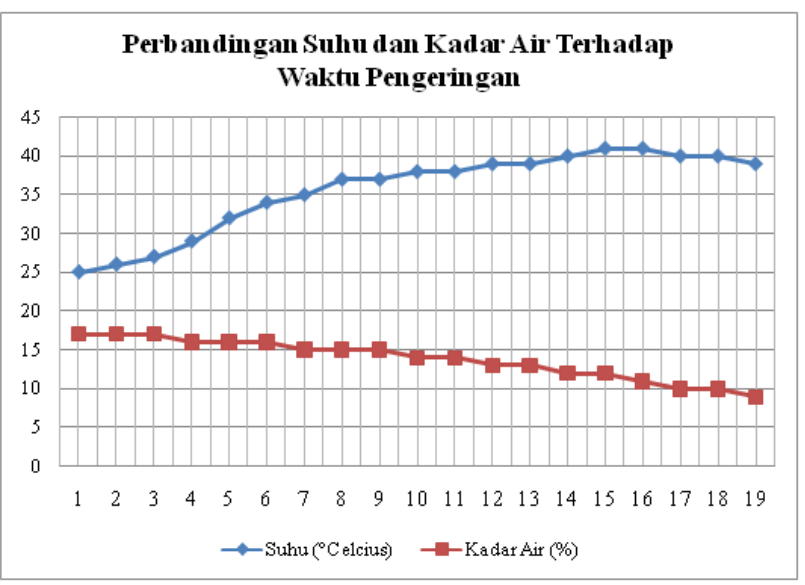

Gambar 18. Perbandingan suhu dan kadar air terhadap waktu pengeringan

\section{Pengujian Output Defuzzifikasi}

Pada output fuzzyfikasi, penetapan rule berdasarkan fuzzy yang telah ada pada program arduino kemudian akan disesuaikan dengan berdasarkan hasil fuzzyfikasi antara sensor soil moisturedan sensor suhu. Pada arduino setiap input yang diberikan akan dimasukan kedalam sub program pada masing-masing rule.

Untuk memastikan data output dari sistem sesuai dengan konsep fuzzy yang 
telah dibuat sebelumnya, maka dilakukan perbandingan proses fuzzy logic kontrol berdasarkan teori dengan hasil yang didapat. Sebuah sistem fuzzy terdiri dari 3 bagian, fuzzyfikasi, mesin inferensi dan defuzzyfikasi. Pada tahap fuzzyfikasi maka input yang ada akan akan dibuat membership fuzzy. Pada pengujian input crip yang didapatkan dari sensor soil moisture dan sensor suhu dikelompokan ke dalam membership fuzzy untuk tahan fuzzyfikasinya.

Setelah penentuan rule fuzzy maka tahap berikutnya adalah defuzzyfikasi untuk mengeluarkan output PWM sesuai dengan yang diharapkan. Berdasarkan rancangan sebelumnya output PWM dari 0-255 memunyai 5 membership, maka setelah proses fuzzyfikasi dari data sensor soil dan suhu pemprosesan penentuan rule pada program arduino maka hasil defuzzyfikasi akan sesuai dengan tabel dibawah ini:

Tabel 5. Hasil defuzzyfikasi

\begin{tabular}{|cccccc|}
\hline No & $\begin{array}{c}\text { Soil } \\
\text { Moisture }(96)\end{array}$ & $\begin{array}{c}\text { Suhu } \\
\left({ }^{\circ} \mathrm{C}\right)\end{array}$ & $\begin{array}{c}\text { MF Soil } \\
\text { Moisture }\end{array}$ & MF Suhu & Rule \\
\hline $\mathbf{l}$ & 17 & 25 & M, AT & S & L \\
\hline $\mathbf{2}$ & 16 & 32 & M, AT & S & L \\
\hline $\mathbf{3}$ & 14 & 38 & AR, M & AP & AL \\
\hline $\mathbf{4}$ & 12 & 41 & R, AR & P, SP & Se, AC \\
\hline $\mathbf{5}$ & 10 & 40 & R & P & Se \\
\hline
\end{tabular}

\section{PEMBAHASAN}

Besaran nilai yang terbaca pada sensor suhu tipe LM35DZ sangat berpengaruh terhadap range panas suhu pada pengering tembakau, dibutuhkan kecocokan antara nilai pembacaan sensor dengan nilai dari alat ukur suhu yang telah terkalibrasi sebelumnya. Nilai suhu yang bagus untuk pengeringan tembakau adalah berkisar antara $35-45^{\circ} \mathrm{C}$. Berdasarkan pengujian yang telah dilakukan pada sensor suhu tipe LM35DZ hampir sama dengan nilai yang terbaca pada Thermometer. Pada pengujian ini kita melakukan perbandingan nilai yang terukur pada mikrokontroller Arduino Uno dengan nilai yang terbaca pada Thermometer. Hasil yang sama hampir didapatkan diantara keduanya. Nilai pada Thermometer sudah merupakan hasil kalibrasi skala suhu dari pabrikan Thermometer, sedangkan pada sensor suhu tipe LM35DZ yang digunakan bekerja berdasarkan program kalibrasi sensor yang diberikan ke sensor melalui program pada mikrokontroller Arduino Uno.

Error rata-rata dari hasil perbandingan pembacaan kadar air dari Moisture tester dengan sensor Soil Moisture adalah 10,6. Hal tersebut dikarenakan range pembacaan kadar air dari Moisture tester adalah 1-10. Dengan kata lain besarnya kadar air yang terukur pada Moisture tester paling kecil adalah 1 sedangkan paling kecil yang terukur pada sensor Soil Moisture adalah 0. Dari data hasil pembacaan kedua alat ukur kadar air tersebut disimpulkan bahwa kadar air yang terbaca antara Moisture tester dengan sensor Soil Moisture tipe YL-69 bisa dikatakan sama. Setelah pengujian sensor Soil Moisture tipe YL-69 dilakukan maka didapatkan hasil yaitu semakin basah tembakau yang diukur maka nilai presentase kadar airnya semakin tinggi, hal ini dikarenakan jumlah kandungan air pada tembakau basah lebih banyak daripada kandungan air pada tembakau kering. Kandungan air inilah yang menentukan besar kecilnya nilai resistansi/tahanan pada tembakau.

Rangkaian relay berfungsi sebagai saklar untuk menghidupkan dan mematikan relay. Jika di listing program kita menuliskan perintah digital Write (relay, $L O W$ ) maka mikrokontroller Arduino Uno akan mengirimkan tegangan sebesar 0.01 Volt atau dengan kata lain tegangan yang masuk ke dalam rangkaian relay hanya sebesar 0.01 Volt. Oleh karena itu relay tidak aktif. Namun jika di listing program kita menuliskan perintah digitalWrite(relay, HIGH)maka

mikrokontroller Arduino Uno akan mengirimkan tegangan sebesar 4.25 Volt. Artinya relay aktif dengan ditandai dengan hidupnya LED yang pada rangkaian ini difungsikan sebagai indikator bahwa relay telah aktif. Transistor akan mengalami 
cutoff apabila arus yang melalui kaki basis sangat kecil sekali sehingga kolektor dan emitor akan seperti kawat yang terbuka. Dan sebaliknya transistor akan mengalami jenuh atau saturasi apabila arus yang melalui basis besar sehingga antara kolektor dan emitor bagaikan kawat yang terhubung, dengan begitu akan merubah kontak relay dari NC (Normally Closed) menjadi NO (Normally Open).

PWM merupakan suatu metoda untuk mengatur kecepatan perputaran motor dengan cara mengatur persentase lebar pulsa high terhadap perioda dari suatu sinyal persegi dalam bentuk tegangan periodik yang diberikan ke motor sebagai sumber daya. Semakin besar perbandingan lama sinyal high dengan perioda sinyal maka semakin cepat motor berputar. Setiap perubahan PWM dipengaruhi oleh resolusi dari PWM itu sendiri. Misalkan PWM digital 8 bit berarti PWM tersebut memiliki resolusi 2 pangkat 8 yaitu 256, dengan artian bahwa nilai keluaran PWM ini memiliki 256 variasi. Variasinya mulai dari 0 sampai 255 yang mewakili duty cycle 0 sampai $100 \%$ dari keluaran PWM tersebut. Pada pengaturan kecepatan motor tersebut, sinyal PWM akan diatur secara digital yang dibangkitkan oleh mikrokontroller Arduino Uno.

Pada variasi PWM 0, tidak terdapat pulsa on. Pada kondisi tersebut motor mati, hal tersebut dikarenakan hanya terdapat pulsa off pada 1 perioda gelombang. Pada variasi PWM 75, lebar pulsa onadalah sebesar 30\% dari total duty cycledalam satu perioda gelombang dan $70 \%$ merupakan lebar pulsa off. Pada variasi PWM 175, lebar pulsa onadalah sebesar $70 \%$ dari total duty cycledalam satu perioda gelombang dan 30\% merupakan lebar pulsa off.Pada variasi PWM 200, lebar pulsa onadalah sebesar $80 \%$ dari total duty cycledalam satu perioda gelombang dan $20 \%$ merupakan lebar pulsa off. Sedangkan pada variasi PWM 255, tidak terdapat pulsa off. Pada kondisi tersebut kecepatan motor maksimal karena hanya terdapat pulsa on pada 1 perioda gelombang penuh.
Setelah mendapatkan hasil pada alat pengering tembakau. Suhu berubah dalam setiap menit, terkadang suhu tidak mengalami perubahan. Meskipun suhu berubah bisa dikatakan konstan pada $38^{\circ} \mathrm{C}$. Hal ini sesuai dengan set point yang diinginkan. Untuk nilai kadar air pada tembakau sesuai dengan grafik di atas, kadar air yang terkandung dalam tembakau akan mengalami penurunan seiring dengan lamanya waktu proses pengeringan. Proses pengeringan dilakukan dengan cara meletakkan tembakau pada rak pengering yang berada dalam box pengeringan. Heater akan aktif dan menaikan suhu didalam box. Sensor LM35 dan sensor kelembaban berada didalam box pengering untuk membaca perubahan suhu dan membaca kadar air. Pengambilan data dilakukan dengan cara menampilkan nilai suhu, nilai kelembaban, waktu dan nilai kecepatan motor fan pada serial monitoring Arduino. Sementara untuk hasil pengukuran nantinya kita menampilkan hasil pada sebuah LCD, program serial monitoring Arduino diganti dengan program serial print LCD sehingga data pengukuran data ditampilkan pada LCD.

Pada awal pengujian suhu berada pada $25^{\circ} \mathrm{C}$ dan kelembaban terbaca $17 \%$. Nilai kecepatan motor yang dihasilkan berdasarkan kenaikan suhu dan kelembaban yang terbaca. Kipas (motor exhaust fan) disini berfungsi untuk menjaga penurunan dan kenaikan suhu yang terjadi agar didapatkan kondisi suhu normal ( $\geq 35^{\circ} \mathrm{C}-\leq$ $45^{\circ} \mathrm{C}$ ). Selisih perubahan suhu yang terjadi setelah pencapaian set point awal, sesuai dengan pengondisian suhu normal.

Apabila kadar air pada tembakau telah sesuai dengan yang diinginkan yaitu $10 \%$ maka secara otomatis heatersebagai pemanas akan diputus sehingga tidak lagi mengeringkan. Pada saat yang bersamaan motor Exhaust fanmasih berada dalam kondisi berputar untuk mendinginkan suhu panas yang masih tersisa dalam box pengering. Secara keseluruhan alat ini telah bekerja dengan baik karena telah sesuai dengan yang diharapkan. 
Output PWM yang dihasilkan oleh sistem dibandingan dengan rentang rule yang telah difuzzyfikasi sebelumnya. Pada data perbandingan pertama kelembaban terbaca $17 \%$, kelembaban tersebut masuk keanggotaan menengah(M) dan agak tinggi(AT), sedangan suhu terbaca $25^{\circ} \mathrm{C}$ dan masuk keanggotaan sedang(S), hasil perbandingan tersebut dihasilkan rule PWM lemah(L), PWM motor yang dihasilkan pada alat dikategorikan lemah(L) yaitu 28 . percobaan kedua kelembaban terbaca $16 \%$, kelembaban tersebut masuk keanggotaan menengah(M) dan agak tinggi(AT), sedangan suhu terbaca $32^{\circ} \mathrm{C}$ dan masuk keanggotaan sedang $(\mathrm{S})$, hasil perbandingan tersebut dihasilkan rule PWM lemah(L), PWM motor yang dihasilkan pada alat dikategorikan lemah(L) yaitu 32. Pada percobaan ketigakelembaban terbaca $14 \%$, kelembaban tersebut masuk keanggotaan agak rendah(AR) dan menengah(M), sedangan suhu terbaca $38^{\circ} \mathrm{C}$ dan masuk keanggotaan agak panas(AP), hasil perbandingan tersebut dihasilkan rule PWM lemah(L), PWM motor yang dihasilkan yaitu 42 dan dikategorikan agak lambat(AL).

Setelah melakukan perbandingan antara rule yang telah difuzzyfikasi dengan data yang telah dihasilkan maka output PWM yang dihasilkan sesuai dengan rentang rule yang telah difuzzyfikasi.

\section{SIMPULAN}

Dari hasil yang diperoleh dengan menngunakan alat sistem pengeringan tembakau ini dapat disimpulkan sebagai berikut :

1. Proses pengeringan tembakau dengan menggunakan alat yang dilakukan hingga mencapai kadar air $10 \%$ memerlukan waktu rata-rata adalah 15 menit.

2. Kadar air dalam tembakau apabila proses pengeringan dilakukan akan mengalami penurunan rata-rata sebesar $0.45 \% /$ menit.

\section{DAFTAR PUSTAKA}

D.E.A. Naba, 2009. Belajar Cepat Fuzzy Logic Menggunakan Matlab, Jogjakarta: Andi Publisher

Karo,Trudly. 2016. Spesifikasi Elemen Pemanas Persegi Panjang.

Malvino, Albert Paul (diterjemahkan oleh Hanapi Gunawan). 1999. Prinsipprinsip elektronik. Erlangga. Ciracas,Jakarta

Tirtosastro, Samsuri 1992. Analisis Pengering Daun Tembakau Rajangan Menggunakan Pengering Ganda.

Wardhana, Lingga 2006, Belajar Sendiri Mikrokontroler AVR Seri ATMega32 Simulasi, Hardware, Aplikasi, Andi Offset, Yogyakarta.

Nise, Norman S., Control Systems Engineering, ed. 3, John Wiley \& Sons

Phillips, Charles L \& Nagle, H. Troy, Digital Control System Analysis \& Design, ed. 3, Prentice Hall 